\title{
IMPROVEMENT QCM QUALITY BY POLYSTYRENE COATING AND BOVINE SERUM ALBUMIN AS IMMOBILIZATION AGENT
}

\author{
Lalu A. Didik*1, Yahdi' ${ }^{2}$, Masruroh ${ }^{3}$ \\ ${ }^{1}$ Departement of Physics Education, Universitas Islam Negeri Mataram, Mataram, Indonesia \\ ${ }^{2}$ Departement of Chemistry Education, Universitas Islam Negeri Mataram, Mataram Indonesia \\ ${ }^{3}$ Departement of Physics, Brawijaya University, Malang, Indonesia \\ *Correspondence address: laludidik@uinmataram.ac.id
}

Received: January $6^{\text {th }}, 2019$. Accepted: April 18 ${ }^{\text {th }}, 2019$. Published: April 29 ${ }^{\text {th }}, 2019$

\begin{abstract}
Polystyrene (PS) thin film with various concentration of mass (1\%, 3\%, and 5\%) has been deposited onto Quartz Crystal Microbalance (QCM) surface by a spin coating method. The purpose of this research is the improvement of Bovine Serum Albumin (BSA) immobilization into the QCM surface. The QCM resonance frequency has been investigated by means of Impedance Analyzer. The film thickness was calculated by the Sauerbrey equation. The surface roughness of the PS layer was observed by noncontact Topography Measuring System (TMS-1200). Calculation result using a Sauerbrey equation shows the thickness of the PS layer increases with the increasing PS concentration. The QCM/PS with 1\% and 5\% concentration of mass has rougher morphology and more frequency shifts caused by BSA injection compared to $3 \%$ concentration of PS.
\end{abstract}

(O2019 Physics Education, UIN Raden Intan Lampung, Indonesia

Keywords: immobilization, polystyrene, quartz crystal microbalance, surface roughness, thin films

\section{INTRODUCTION}

A biosensor is an analytical instrument which utilizes biomolecule to detect certain chemical substance through physical-chemical transduction (Makhneva, Manakhov, Skládal, \& Zajíčková, 2016; Manclús et al., 2014).

The elements of this transduction can take the form of the optical, electrochemical, calorimetric, magnetic, or mass-sensitive (piezoelectric) transducer. According to the types of biological elements used, the biosensor can be categorized into two groups: catalyst and affinity biosensor (Connie, Lauren, \& Wen, 2019; Dong, Jin, $\&$ Zhao, 2018).

QCM is a piezoelectric affinity biosensor type which is based on the coupling between the introduction of immobilized biomolecule and piezoelectric effect. The underlying theory that implies QCM as the mass-sensitive sensor is the Sauerbraten equation (Didik, Rahmawati, Robiandi, Rahayu, \& Santjojo, 2014; Karczmarczyk, Haupt, \&
Feller, 2017; Makhneva et al., 2016; Manclús et al., 2014)

$$
\Delta f=-2 \frac{f_{0}^{2}}{\sqrt{\rho_{q} \mu_{q}}} \frac{\Delta m}{A}
$$

Where $\Delta \mathrm{m}$ is the mass change on the surface of the sensor, $\mathrm{f}_{0}$ is the threshold frequency of QCM, A refers to the area of the electrode surface, $\rho_{q}$ is the crystal density of QCM $\left(2,648 \mathrm{~g} / \mathrm{cm}^{3}\right)$, and $\mu_{q}$ is modulus shear $\left(2,947 \times 10^{-11} \mathrm{~g} / \mathrm{cm}^{2} \mathrm{~s}^{2}\right)$ of QCM sensor.

The frequency of QCM resonance alteration due to the change of mechanical characteristics of the material is linked to the dissipation of acoustic energy and the transmission of the acoustic wave inside the material (Masruroh et al., 2014; Sakti, Masruroh, Sabarudin, Santjojo, \&Khusnah, 2018). When resonance takes place, QCM oscillator can be assumed to be in an electrical circuit frequently called Butterworth-van Dyke (BVD) model. 


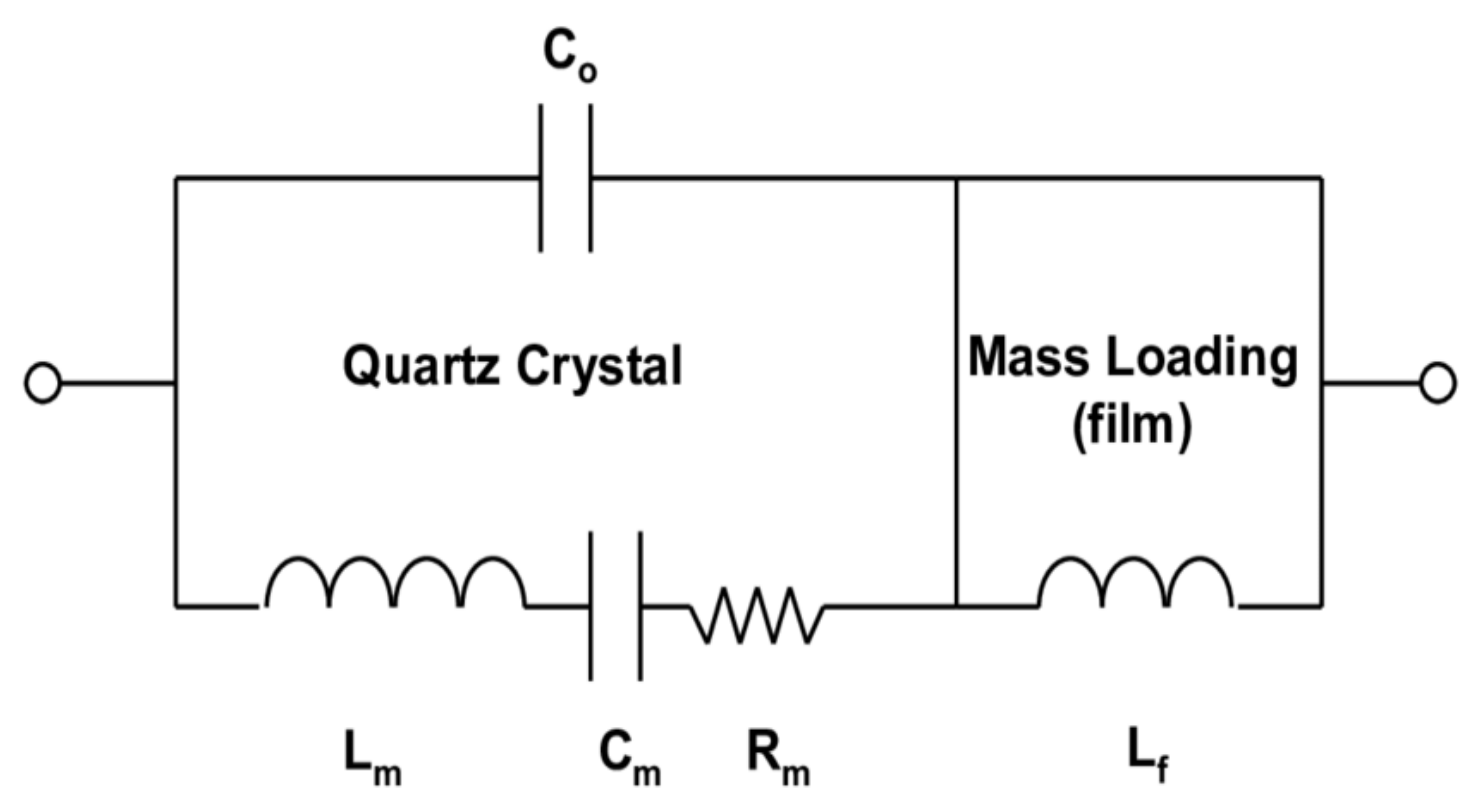

Figure 1. Butterworth-van Dyke Model to illustrate the electrical characteristics of QCM

Figure 1 Show that BVD model comprises two parts. The first part consists of components whose values are varying due to mass pressure and crystal viscosity. The components are (1) $\mathbf{R}$ (resistor) showing energy dissipation of quartz crystal oscillation. (2) C (capacitor) showing the accumulated energy during oscillation and the elasticity of crystal quartz. (3) $\mathbf{L}$ (inductor) showing oscillation inertia component related to mass change during vibration. The first hand is a parallel set with static capacitance $\mathbf{C}_{\mathbf{0}}$ indicating the number of electrodes, holder, and connector capacitances of quartz crystal (Chen, $\mathrm{Xu}$, Liu, Masliyah, \& Xu, 2015; Piñón-Pazos, Calvo-Rolle, Rodríguez-Gómez, Casteleiro-Roca, \& Meizoso-Lopez, 2014).

QCM boasts a high level of accuracy since it has the sensitivity of oscillation frequency on certain temperature, humidity, pressure, velocity, and vibration (Manclús et al., 2014; Wang et al., 2016). The oscillation frequency of QCM depends on its physical size and the thickness of the crystal.

If the surface of the QCM sensor used to immobilize protein is not flat, even tends to be rough, it might be predicted that more biomolecules are attached to the sensor surface. In this case, the size of the QCM surface does not alter, yet will improve the mass value per size of QCM area. This rough surface will yield more immense mass change if compared to flat biosensor surface (Dultsev \& Nekrasov, 2018; Karczmarczyk et al., 2017; Masruroh et al., 2014; Park \& Lee, 2018).

The thickness of monolayered protein due to absorption is relatively smaller in comparison to the length of acoustic wave triggered by the sensor (Sakti et al., 2018; Yang, Li, Chen, \& Mercadé-prieto, 2017). Since the formed layer is really thin, while the threshold frequency is really high, the antigen/antibody can be assumed to form a thin layer. Consequently, the viscosity effect is extremely small that it can be ignored. Therefore, Saurberey equation can be used.

\section{METHOD}

\section{Sample Preparation}

PS was dissolved at a concentration level of $1 \%, 3 \%$ and $5 \%$ using Chloroform solvent. The PS liquid was then dispositioned using spin coating method (Rotation speed of $3000 \mathrm{rpm}$ in $60 \mathrm{sec}$ ) 
above QCM surface (Threshold frequency $10 \mathrm{MHz}$ ) whose initial frequency was once measured using Impedance Analyzer type Bode $100\left(\mathrm{f}_{0}\right)$. The QCM frequency, after layered by polystyrene, was re-measured $\left(f_{1}\right)$ to find out the frequency alteration $(\Delta f)$.

\section{Determining the Thickness of Layer Using Modified Sauerbrey Equation}

The calculation of PS layer thickness used modified Sauerbrey equation (Didik et al., 2014).

$$
\Delta h=-\left[\frac{\Delta f}{f_{o}^{2}}\right] 4206,5 \mathrm{~m}
$$

The calculation of thickness above was under an assumption that PS layered above QCM surface was during rigid body phase and had small porosity.

\section{Characterizing the Morphology of QCM/PS Layer}

The characterizing of layer utilized non-contact Topography Measurement System type TMS-1200 to obtain the data of layer morphology and surface roughness.

\section{Immobilizing Bovine Serum Albumin (BSA).}

PBS (Phosphate Buffer Saline) and BSA (Bovine Serum Albumin) were obtained from Sigma Aldrich. PBS $70 \mu \mathrm{l}$ as a buffered solvent was deposited onto QCM surface within cell construction. After the reading of frequency at frequency counter had been stable, BSA was deposited at a concentration level of $600 \mathrm{mg} / \mathrm{l}$ of $30 \mu \mathrm{l}$.

Figure 2 Shows the frequency change resulted from the immobilization was measured from stable frequency after PBS was deposited up to the one after BSA was deposited. The stable criterion, in this case, was when the QCM frequency was within the range of $\pm 3 \mathrm{~Hz}$ during the duration of \pm 200 seconds (Masruroh et al., 2015).

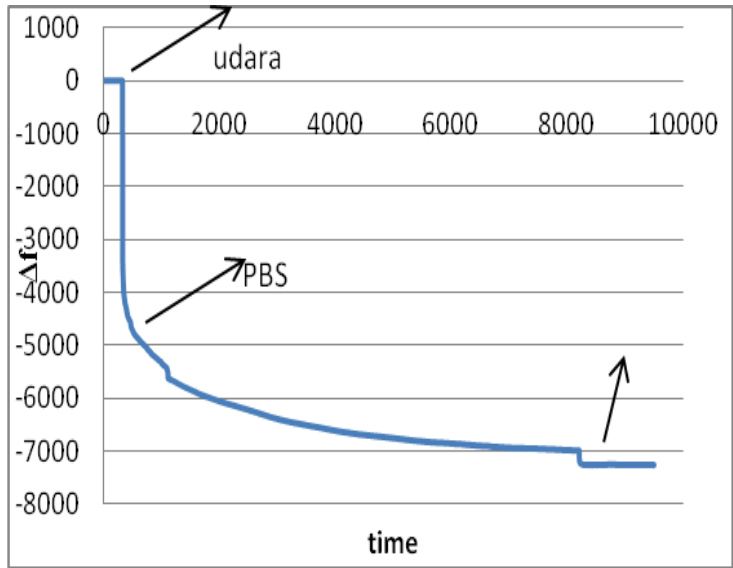

Figure 2. Graph showing the relationship between QCM frequency alteration and time during BSA immobilization process.

\section{RESULTS AND DISCUSSION}

The measurement of QCM frequency resonance after layered by PS at various level of concentration using Impedance Analyzer is shown in Figure 3.

The resulted Polystyrene film is within a rigid body parameter based on data impedance by impedance analyzers illustrated in Figure 3. The peak of the impedance is still measurable hence the value of QCM frequency resonance can be determined.

The graph peak shows an occurrence of resonance. Based on a circuit parallel to BVD, the relationship between frequency and impedance can be determined (Chen et al., 2015; Piñón-Pazos et al., 2014)

Hence the value of QCM resonance frequency can be determined through the following equation,

$$
f=\frac{1}{2 \pi} \sqrt{\frac{1}{L C}}
$$

The impedance-frequency graph will sharply go down due to the minimum impedance value. The QCM resonance frequency is then determined in this situation. The next curve goes up and will go sharply when the value of $\left|\mathrm{X}_{\mathrm{L}}-\mathrm{X}_{\mathrm{C}}\right| \neq 0$. In this condition, the impedance reaches a maximum value (Piñón-Pazos et al., 2014). 

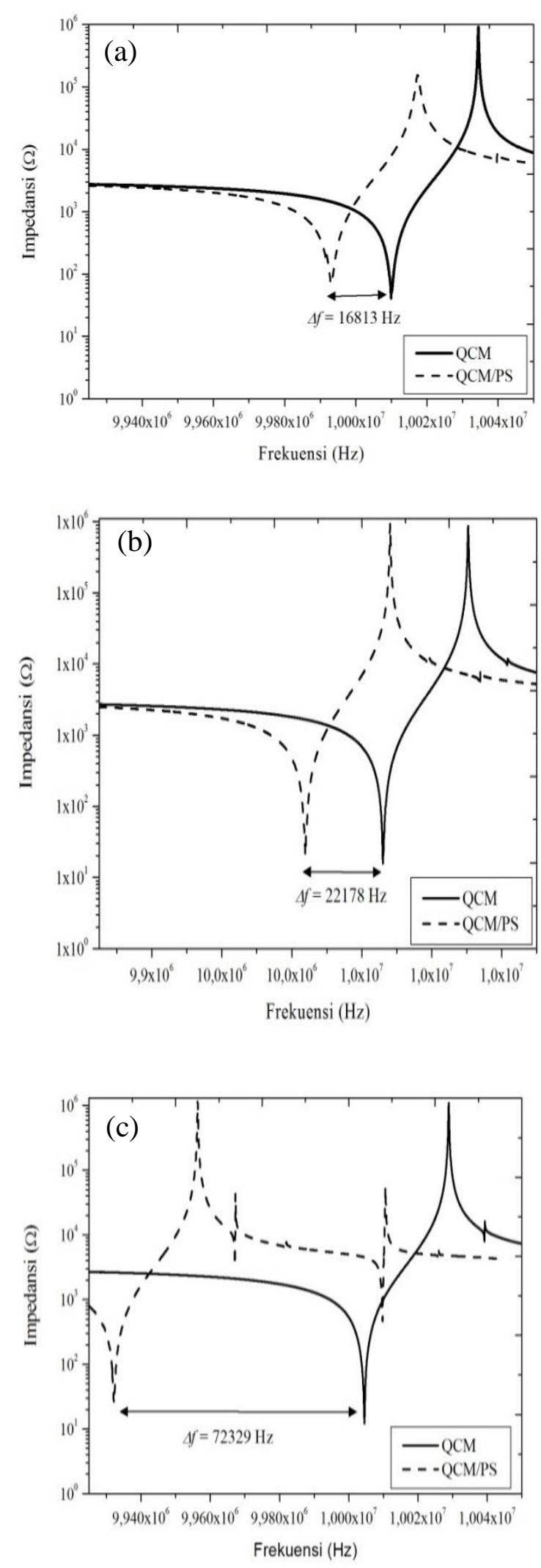

Figure 3. Graph showing the relationship between QCM frequency and impedance based on measurement by Impedance Analyzer Mass Concentration (a) 1\%, (b) 3\%, (c) Mass Concentration 5\%
The increase of mass at the QCM surface brings about the increase of inductance value. As a result, the value of frequency resonance will decrease since the frequency is in reverse with the inductance (Sakti et al., 2018). This is shown by the move of the minimum peak toward the left direction in the frequencyimpedance graph. The difference between QCM resonance frequency before and after layering shows frequency changes $(\Delta \mathrm{f})$. Using Saurbrey equation, the layer thickness can be determined as shown in table 1 .

Table 1 The layer thickness of QCM/PS based on a calculation using the Sauerbrey equation

\begin{tabular}{llll}
\hline No & $\begin{array}{c}\text { PS } \\
\text { concentration }\end{array}$ & $\begin{array}{c}\text { Frequency } \\
\text { change } \\
(\mathrm{Hz})\end{array}$ & $\begin{array}{c}\text { Layer } \\
\text { thickness } \\
(\mu \mathrm{m})\end{array}$ \\
\hline 1 & $1 \%$ & 16813 & 0,73 \\
\hline 2 & $3 \%$ & 22178 & 0,89 \\
\hline 3 & $5 \%$ & 72329 & 3,93 \\
\hline
\end{tabular}

The profile of the PS layer surface characterized using TMS 1200 is shown in figure 4. The peak-to-peak distance between the shortest graphs is at a concentration of $1 \%$ and the longest one is at a concentration of $5 \%$. This shows that the smallest thickness is at a concentration of $1 \%$ and the biggest one is at a concentration of $5 \%$.

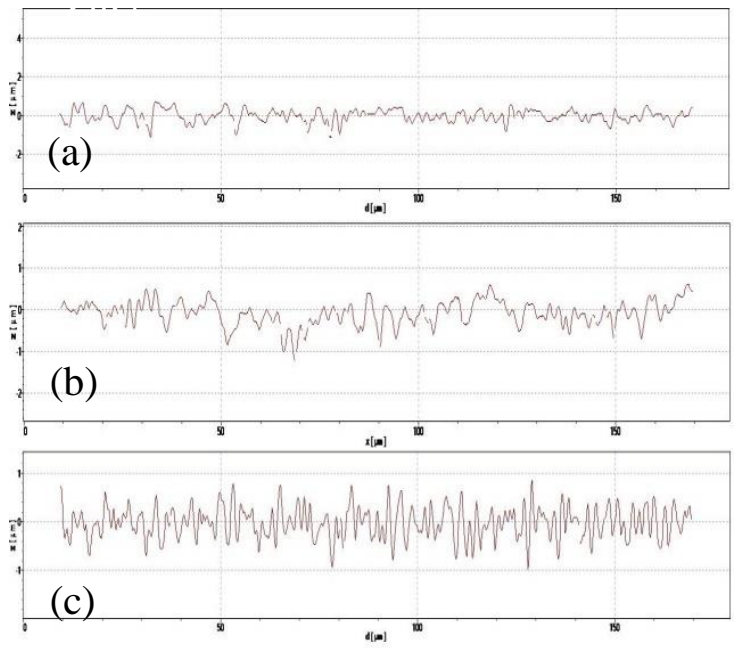

Figure 4. The profiles of PS surface layer with a variety of mass concentrations (a) $1 \%$, (b) $3 \%$, (c) $5 \%$ 
Figure 5 shows the measurement results of surface toughness using TMS1200. The surface roughness of the polystyrene surface layer with each concentration $1 \%, 2 \%$, and $3 \%$ is 248,33 $\mathrm{nm} ; 207,99 \mathrm{~nm}$ and 246, $30 \mathrm{~nm}$.

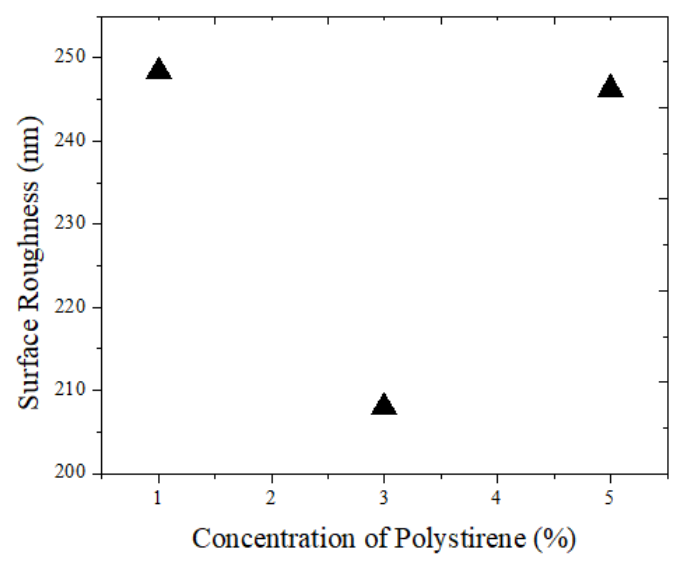

Figure 5. The graph of the relationship between the variation of PS concentration and surface roughness.

The level of surface roughness at a concentration of $1 \%$ is at almost the same value as that of a concentration of $5 \%$. In the case of PS concentration of $1 \%$, the liquid yielded is quite diluted. As a consequence, when the layering uses spin coating method, the centrifugal force can lure the PS layer to become more expanded therefore the yielded layer is thinner and the level of toughness is determined by the size of the surface peak (Didik et al., 2014).

Whereas at a concentration of $5 \%$, vast viscosity will bring about the layer to be hardly pulled and expanded by centrifugal force resulted from spin coater. Consequently, the formed layer is thicker and layer toughness is determined by the height of layer surface peak (Park \& Lee, 2018; Speller, Siraj, Vaughan, Speller, \& Warner, 2017).

The smallest surface toughness occurs when the biggest layer concentration is $3 \%$. In numerous applications, the sensor surface is made flat to avoid damping effect (Deniz \& Deligöz, 2019; Masruroh et al., 2014; Sakti et al., 2018). Therefore, the optimum concentration parameter for PS layer above the QCM surface should be $3 \%$.

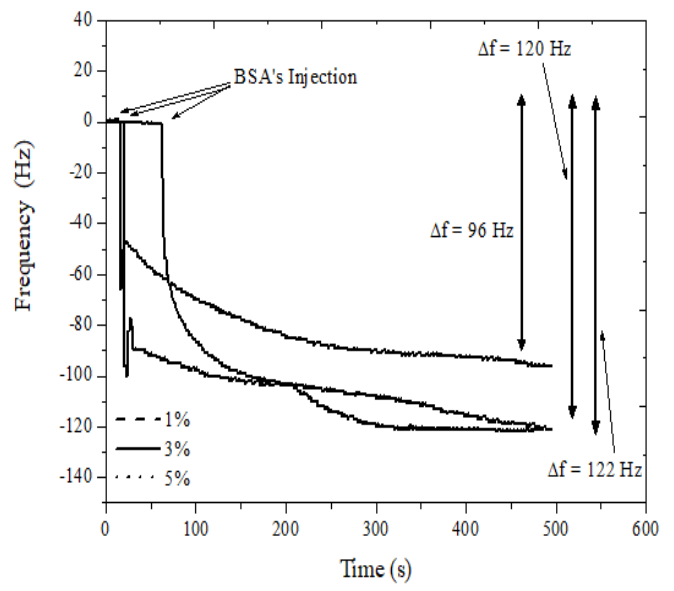

Figure 6. QCM frequency changes as a result of BSA immobilization.

The result of BSA immobilization above QCM/PS surface shown by Figure 6. It is shown that with smaller surface roughness, PS layer with a concentration of $3 \%$ yields smaller frequency changes when compared to the polystyrene layer with a concentration of $1 \%$ and $5 \%$. PS layer with $3 \%$ concentration has a smaller surface roughness (Figure 5) caused by the effect of saturation PS deposited by a spin coating method, therefore PS layer with 3 $\%$ concentration immobilize lower BSA. BSA immobilize is trapping system immobilization (Masruroh et al., 2015; Speller et al., 2017). Because of smaller surface roughness, QCM/PS with 3\% concentration has a smaller space for trapping BSA.

\section{CONCLUSION}

Various concentration of PS layered above the QCM surface will bring about different layer thicknesses. The higher the PS concentration, the thicker the layers yielded are. Flatter layer is produced when the concentration of the layered PS is $3 \%$. However, the most notable frequency change due to BSA immobilization is when the PS concentration is of $1 \%$ and 5 $\%$. This is due to the fact that the level of layer surface toughness with PS 
concentration of 5\% is higher if compared to the PS layer with a concentration of $3 \%$. Nevertheless, the PS layer with concentration will yield more stable QCM since the flatter surface helps avoid damping effect on the QCM sensor.

\section{ACKNOWLEDGMENT}

The author would like to thank the staff of Laboratorium Material Universitas Brawijaya which helped provide facilities for synthesis and characterization QCM/PS sensor.

\section{REFERENCES}

Chen, Q., Xu, S., Liu, Q., Masliyah, J., \& $\mathrm{Xu}$, Z. (2015). QCM-D study of nanoparticle interactions. Advances in Colloid and Interface Science. https://doi.org/10.1016/j.cis.2015.10. 004.

Connie, W., Lauren, G., \& Wen, Z. (2019). Real-Time Interaction of MixedSpecies Biofilm With Silver Nanoparticles Using QCM-D. Colloid and Interface Science Communications. 28, 49-53. https://doi.org/10.1016/j.colcom.201 8.11.007.

Deniz, M., \& Deligöz, H. (2019). Flexible self-assembled polyelectrolyte thin films based on conjugated polymer: Quartz crystal microbalance dissipation (QCM-D) and cyclic voltammetry analysis. Colloids and Surfaces A, 563, 206-216. https://doi.org/10.1016/j.colsurfa.201 8.12.014.

Didik, L. A., Rahmawati, E., Robiandi, F., Rahayu, S., \& Santjojo, D. J. D. H. (2014). Penentuan Ketebalan Lapisan Polistiren dan Zinc Phthalocyanine (ZnPc) dengan Modifikasi Persamaan Sauerbrey dan Scanning Electron Microscope (SEM). Natural B, 2(4), 331-335.

Dong, Z., Jin, X., \& Zhao, G. (2018). Biosensors and Bioelectronics Ampli fi ed QCM biosensor for type IV collagenase based on collagenasecleavage of gold nanoparticles functionalized peptide. Biosensors and Bioelectronic, 106, 111-116. https://doi.org/10.1016/j.bios.2018.0 1.069 .

Dultsev, F. N., \& Nekrasov, D. V. (2018). Treatment of the resonance curve recorded during measurement of the signal of particle rupture from the QCM surface. Sensors \& Actuators: $B$.

Chemical. https://doi.org/10.1016/j.snb.2018.04 .029 .

Karczmarczyk, A., Haupt, K., \& Feller, K. H. (2017). Development of a QCM-D biosensor for Ochratoxin A detection in red wine. Talanta, 166, 193-197. https://doi.org/10.1016/j.talanta.2017 .01 .054 .

Makhneva, E., Manakhov, A., Skládal, P., \& Zajíčková, L. (2016). Development of effective QCM biosensors by cyclopropylamine plasma polymerization and antibody immobilization using cross-linking reactions. Surface and Coatings Technology, 290, 116-123. https://doi.org/10.1016/j.surfcoat.201 5.09.035.

Manclús, J. J., Arnau, A., García, P., March, C., Sánchez, Á., Montoya, Á., García, J. V. (2014). High-frequency phase shift measurement greatly enhances the sensitivity of QCM immunosensors. Biosensors and Bioelectronics, 65, 1-8. https://doi.org/10.1016/j.bios.2014.1 0.001 .

Masruroh, Djoko, D. J. D. H., Didik, L. A., Rachmawati, E., Robiandi, F., Padaga, M., \& Sakti, S. P. (2015). Modification of polystyrene morphology and its influence to the coated zinc phthalocyanine layer and frequency change in QCM sensor. Materials Science Forum, 827. https://doi.org/10.4028/www.scientif 
ic.net/MSF.827.257.

Masruroh, Djoko, D. J. D. H., Didik, L. A., Rahmawati, E., Pagaga, M., Abdurrouf, \& Sakti, S. P. (2014). Solvent effect on morphology of polystyrene coating and their role to improvement for biomolecule immobilization in application of QCM based biosensor. Applied Mechanics and Materials, 530-531. https://doi.org/10.4028/www.scientif ic.net/AMM.530-531.54.

Park, H. J., \& Lee, S. S. (2018). A quartz crystal microbalance-based biosensor for enzymatic detection of hemoglobin A1c in whole blood. Sensors and Actuators, B: Chemical, 258 , 836-840. https://doi.org/10.1016/j.snb.2017.11 .170 .

Piñón-Pazos, A., Calvo-Rolle, J. L., Rodríguez-Gómez, B. A., CasteleiroRoca, J. L., \& Meizoso-Lopez, M. C. (2014). New approach for the QCM sensors characterization. Sensors and Actuators A: Physical, 207, 1-9. https://doi.org/10.1016/j.sna.2013.12 .002 .

Sakti, S. P., Masruroh, Sabarudin, A., Santjojo, D. J. D. H., \& Khusnah, N. F. (2018). Surface Modification of Polystyrene Coating on QCM Sensor using Ambient Air Plasma at Low Pressure. Materials Today: Proceedings, 5(7), 15149-15154. https://doi.org/10.1016/j.matpr.2018. 04.073.

Speller, N. C., Siraj, N., Vaughan, S., Speller, L. N., \& Warner, I. M. (2017). QCM virtual multisensor array for fuel discrimination and detection of gasoline adulteration. Fuel, 199, 38-46. https://doi.org/10.1016/j.fuel.2017.0 2.066 .

Wang, L., Wang, Z., Xiang, Q., Chen, Y., Duan, Z., \& Xu, J. (2016). High performance formaldehyde detection based on a novel copper (II) complex functionalized QCM gas sensor. Sensors \& Actuators: B. Chemical, 9. https://doi.org/10.1016/j.snb.2016.12 .015 .

Yang, W., Li, D., Chen, X. D., \& Mercadéprieto, R. (2017). Effect of calcium on the fouling of whey protein isolate on stainless steel. Chemical Engineering Science.

https://doi.org/10.1016/j.ces.2017.12. 004. 